\title{
EFFECT OF IRRIGATION AND MULCHING ON GROWTH AND YIELD OF GINGER
}

\author{
M.A. Islam ${ }^{1}$, M.A. Rahim ${ }^{2}$ and T.M.T. Iqbal ${ }^{3}$ \\ ${ }^{1}$ Spices Research Center, BARI, Bogra; ${ }^{2}$ BAU, Department of Horticulture, Mymensingh \\ ${ }^{3}$ Department of Horticulture, HSTU, Dinajpur
}

Key words: Ginger, irrigation, mulching

\begin{abstract}
A field experiment was conducted at the Spices Research Center, BARI, Bogra, Bangladesh during 2009-10 to determine the impact of irrigation and suitability of mulch materials on the growth and yield of ginger. The experiment was laid out in the randomized complete block design (RCBD) with three replications. The treatments comprising of two factors viz., two irrigation $\left(\mathrm{I}_{1}\right.$ : irrigation in dry period and $\mathrm{I}_{2}$ : control i.e. no irrigation and three mulching material $\left(\mathrm{M}_{0}\right.$ : control (no mulch) $\mathrm{M}_{1}$ : water hyacinth and $\mathrm{M}_{2}$ : rice straw). Treatment revealed that $\mathrm{I}_{1}$ : (irrigation in dry period) showed that early emergence, highest plant height, number of leaves/plant, number of tillers/plant with maximum weight of primary and secondary rhizome, highest dry matter $\%$ and weight of old mother rhizome t ha ${ }^{-1}$. The highest yield of rhizome (21.19 $t \mathrm{ha}^{-1}$ ) was obtained from $\mathrm{I}_{1}$ : (irrigation in dry period). Among the mulch treatments, the highest rhizome yield $\left(22.51 \mathrm{t} \mathrm{ha}^{-1}\right)$ was obtained from $\mathrm{M}_{2}$ (ricer straw mulch). The combined effect of $\mathrm{I}_{1} \mathrm{M}_{2}$ (irrigation in dry period with rice straw mulch) produced the highest rhizome yield (25.07 $\left.\mathrm{t} \mathrm{ha}^{-1}\right)$.
\end{abstract}

\section{Introduction}

Ginger (Zingiber officinale Rosc.) is an important spice crop in Bangladesh. It is valued for its diversified uses in various drinks, medicines and culinary purposes (Pruthi, 1998). Beside the varietal factor, the yield of ginger can be increased with the adoption of improved agronomic practices, like irrigation and suitable mulch materials. Mulch and irrigation are the two important aspects of ginger production. Generally, farmers depend on unpredicted rainfall, which results in late planting. In the early season, soil remains dry, and therefore irrigation at the early stage is needed for ginger growth. The crop is affected by weed except when mulching and adequate weed control measures are taken during the early the stage of growth. Generally, ginger is cultivated under the rainfed conditions in Bangladesh. As irrigation facilities are inadequate and early monsoon rain is not certain, conservation of residual soil moisture by artificial means is be very useful for the plants in maximizing the growth and production of the crop. Artificial mulches like water hyacinth and rice straw can be used to serve this purpose. Mulch conserves soil moisture and protects sprouting of seed materials from excessive heat and desiccation (Onwueme, 1978). Application of mulch soon after planting is beneficial for the culture of some root and tuber crops (Awal et al., 1978; Jha et al., and 1986). Mulched plot gives higher yield than non-mulched plot (Nick et al., 1969; Mannan and Rashid, 1983). Since soil moisture becomes a limiting factor for emergence and early growth of ginger, the use of mulch may be beneficial. Irrigation and mulch play an important role to increase the yield potential of ginger. Ginger is generally cultivated in kharif season in Bangladesh. Irrigation facilities are inadequate and the early monsoon rain is also uncertain. Thus irrigation and 
Islam et al.

mulching may be the most important factors of ginger production. So, this experiment was undertaken to investigate the effects of irrigation and mulching on the growth and yield of ginger.

\section{Materials and Methods}

The experiment was conducted at the research farm of the Spices Research Centre, BARI, Bogra, during the period from April 2009 to January 2010. It has sub-tropical climate with an average annual rainfall of $237.13 \mathrm{~mm}$. The soil was Tista polal tract, having a $\mathrm{p}^{\mathrm{H}}$ value of 5.86.6. The experiment was laid out in a randomized complete block design (RCBD) with three replications. Healthy ginger rhizome Var. BARI Ada-1 was used for planting material. Two irrigation levels viz., $\mathrm{I}_{1}$ (irrigation in dry period: 7days before planting and 60 days after planting) and $\mathrm{I}_{2}$ (no irrigation) were consisted as the first factor and three mulching materials viz., $\mathrm{M}_{0}$ (control), $\mathrm{M}_{1}$ (water hyacinth) and $\mathrm{M}_{2}$ (rice straw) were considered as the second factor. Planting was done on the $1^{\text {st }}$ April, 2009. The crop was fertilized with cowdung, urea, TSP, MP and gypsum at 5 ton, 304,267, 233 and $111 \mathrm{~kg} \mathrm{ha}^{-1}$, respectively. Total cowdung was applied at the time of general land preparation and the entire quantity of TSP, gypsum and half of MP was applied during the final land preparation. Half of the urea was applied 50 days after planting and the remaining MP and urea were applied in two equal splits at 80 and 110 days after planting. Earthing up was done at 60, 90 and 110 days after planting. The data on different growth parameters were recorded from randomly of 10 selected plants of each plot 15 days interval at 50, 65, 80, 110, 125, 140 and 155 days after planting. Yield and yield contributing characters were collected at harvesting time. The Ist irrigation was applied 7 days before planting and the $2^{\text {nd }}$ irrigation after 60 DAP (Days after planting). Irrigation was done at the level of critical point indicated by moisture meter (delta T England). Irrigation water applied twice $80 \mathrm{~mm}$ each time. Irrigation water was applied twice at 7 days before planting and at 60 days after planting. The discharge of water through hose pipe (Diameter $2.5 \mathrm{~cm}$ ) was calibrated before application. The discharge of water through this pipe was $20 \mathrm{~mm}$ pipe per minute. The mulch materials were covering with the $4 \mathrm{~cm}$ thickness. Water hyacinth and rice straw mulch were placed before the rhizomes started to emerge. A second mulch was added at 60 days after planting as the first one was washed away by rain, wind and irrigation water. Rice straw and water hyacinth were applied at 2.0 and $2.5 \mathrm{~kg} / \mathrm{m}^{2}$; respectively. The soil samples were taken from each plot at 0-10 cm depth before each irrigation. The samples were weighed and oven dried at $100^{\circ} \mathrm{C}$ for 24 hours. The collected data were analyzed statistically and adjusted with least significance (LSD) at 5\% level of probability.

\section{Results and Discussion}

\section{Soil moisture content}

Soil moisture at the field capacity of the experimental plot was 25.4\%. At the beginning, application of mulch in non-irrigated or irrigated plot conserved more moisture compared to non-mulch + no-irrigation plot. At this time, rice straw mulch + no-irrigation conserved about $1.8 \%$ more moisture than water hyacinth + no-irrigation treatment. Similarly rice straw mulch + irrigation conserved about $1.14 \%$ more moisture than water hyacinth + irrigation treatment. Irrigation applied after two months of planting showed that moisture content in rice straw mulch + irrigation conserved more moisture compared to water hyacinth + irrigation and nomulch + irrigation treatments (Table 1$)$. At this time, rice straw mulch + irrigation conserved 
about $1.01 \%$ more moisture than water hyacinth + irrigation treatment. The highest soil moisture was found in irrigation + rice straw mulch $(19.35 \%$ in before planting and $8.65 \%$ in two months after planting) while the lowest moisture control treatment $(17.0 \%)$ before planting and $6.5 \%$ in two months after planting) (Table 1). The rice straw mulch possibly conserved more soil moisture and suppressed weeds (Table 1), which helped plant growth and deposition of more food materials. Similar result was also reported by Ghosh et al. (2007) who observed the maximum yield per plant from the plants under the paddy straw mulch. The influence of mulching treatment was found significant on the rhizome yield.

Table 1. Residual soil moisture contents of the experimental plots at $10 \mathrm{~cm}$ depth at the beginning and two months after planting the crop

\begin{tabular}{l|c|c|c}
\hline Treatment combination & $\begin{array}{c}\text { Moisture content } \\
\text { at the beginning } \\
(\%)\end{array}$ & $\begin{array}{c}\text { Moisture content } \\
\text { after 2 month of } \\
\text { planting (\%) }\end{array}$ & $\begin{array}{c}\text { Moisture at } \\
\text { field capacity } \\
(\%)\end{array}$ \\
\hline Control + No Irrigation & 17.00 & 6.50 & \\
Water hyacinth + No Irrigation & 17.80 & 7.10 & \\
Rice straw + No Irrigation & 18.00 & 8.13 & 25.4 \\
Control + Irrigation in dry period & 17.22 & 6.85 & \\
Water hyacinth + Irrigation in dry period & 18.21 & 7.64 & \\
Rice straw + Irrigation in dry period & 19.35 & 8.65 & \\
\hline
\end{tabular}

Plant height was significantly influenced by irrigation. The highest plant $(71.66 \mathrm{~cm})$ was obtained from the treatment $\mathrm{I}_{1}$ (irrigation in dry period) and the lowest $(60.45 \mathrm{~cm})$ in $\mathrm{I}_{2}$ (control) treatment at the $125 \mathrm{DAP}$ (Fig. 1). The better result in $\mathrm{I}_{1}$ may be due to conserved soil moisture that favored rapid plant growth. This finding agrees with Pawar, 1990; and Singh et al., 2000. Mulch had significant influence on plant height. The tallest plant $(74.29 \mathrm{~cm})$ was found in the treatment $\mathrm{M}_{2}$ (rice straw mulch) while the lowest $\left(57.30 \mathrm{~cm}\right.$ ) in $\mathrm{M}_{0}$ (control) treatment at 125 DAP (Fig. 2).

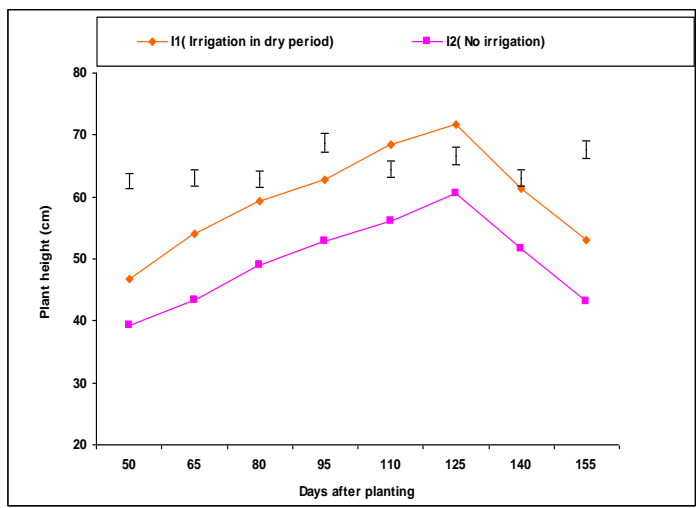

Fig. 1. Main effects of irrigation on the plant height of ginger. Vertical bars represent LSD at $5 \%$ level of probability

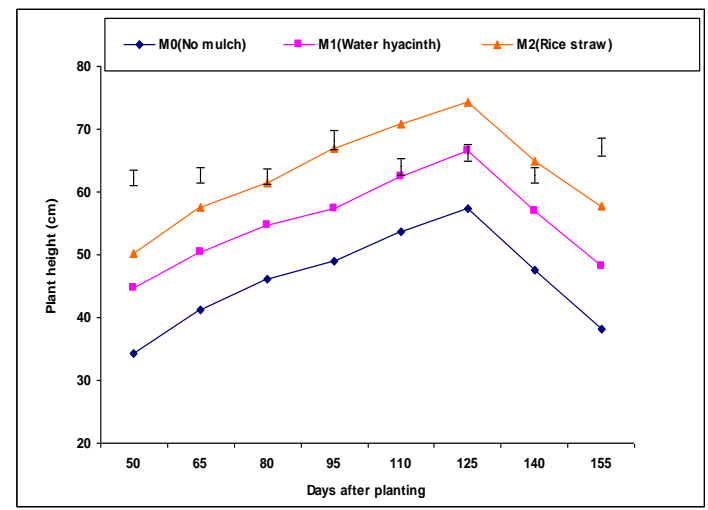

Fig. 2. Main effects of mulching on the plant height of ginger. Vertical bars represent LSD at $5 \%$ level of probability

After 125 DAP, plant height decreased gradually due to senescence of leaves. It might be due to mulching which had reduced the evaporation of soil moisture, weed growth and conserved moisture from rainfall during the early stage of plant growth. Similar result was also reported by Mohanthy et al. (1991), Chandra et al. (2001) and Ghosh et al. (2007). 
Islam et al.

The combined effect of irrigation and mulching on plant height was significant from 50 to 155 DAP. The tallest plant $\left(79.76 \mathrm{~cm}\right.$ ) was recorded from $\mathrm{I}_{1} \mathrm{M}_{2}$ (irrigation in dry period with rice straw mulch) and the shortest plant $\left(50.87 \mathrm{~cm}\right.$ ) from $\mathrm{I}_{2} \mathrm{M}_{0}$ (control) at 125 DAP (Table 4). Possible due to irrigation with rice straw mulching reduced soil temperature, conserved soil moisture, minimize the evaporation loss and enhances root growth and water use efficiency. So, plant was vigorous and rapid growth. This finding agreed with the finding of Zaman et al. (2002) and Mishra and Mishra (1982).

The numbers of leaves per plant were counted at different growth stages and interval of 15 days at 50, 65, 80, 95, 110, 125, 140 and 155 DAP. A significant variation was observed for numbers of leaves per plant at those stages and interval. The highest number of leaves (106.28) was recorded from $\mathrm{I}_{1}$ (irrigation in dry period) and the lowest (88.77) in the $\mathrm{I}_{2}$ (control) treatment at 125 DAP (Fig. 3). Irrigation increased soil moisture content by plants resulting enhanced growth of plants. This finding agrees with Pawar (1990) and Singh et al. (2000). In case of mulch, the maximum number of leaves (129.28) was recorded from $\mathrm{M}_{2}$ (rice straw) while the minimum (70.55) was recorded from $\mathrm{M}_{0}$ (control) treatment at 125 DAP (Fig. 4).

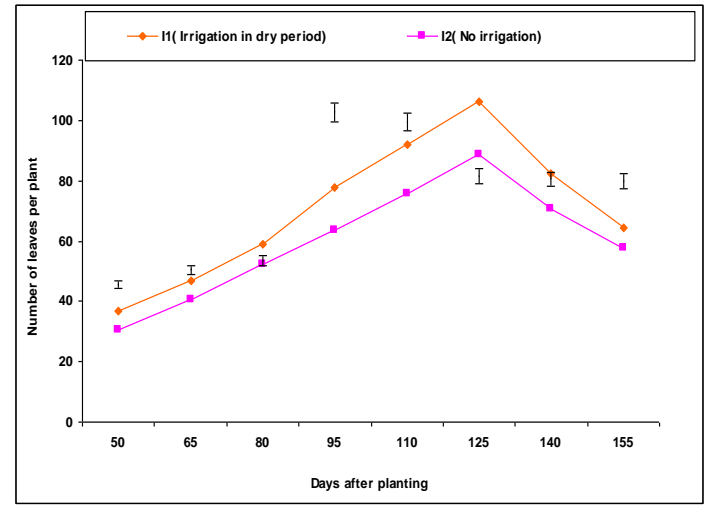

Fig. 3. Main effects of irrigation on the number of leaves per plant of ginger. Vertical bars represent $\mathrm{LSD}$ at $5 \%$ level of probability

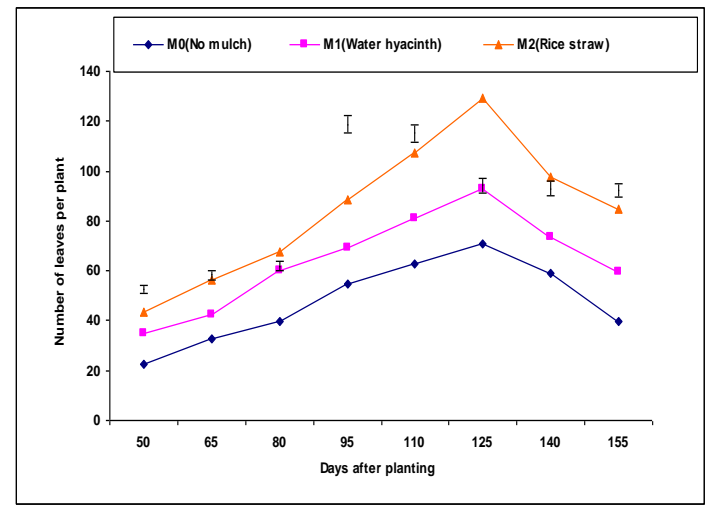

Fig.4. Main effects of mulching on the number of leaves per plant of ginger. Vertical bars represent LSD at 5\% level of probability

Almost similar trend regarding number of leaves per plant was obtained by Ghosh et al. (2007). In case of combined effect the highest number of leaves (141.80) was counted in the $\mathrm{I}_{1} \mathrm{M}_{2}$ (irrigation in dry period with rice straw mulch) while the lowest (62.10) was obtained from $\mathrm{I}_{2} \mathrm{M}_{0}$ (control) treatment combinations at 125 DAP (Table 4). It might be due to that irrigation supplied water and mulch conserved moisture in the soil to some extend which was used by the plants to promote more number of leaves per plants Ghosh (1996) obtained higher number of leaves per plant from rice straw mulch.

The number of tillers per plant was counted at different growth stage at an interval of 15 days viz. 50, 65, 80, 95, 110, 125, 140 and 155 DAP. The highest number of tillers per plant (12.25) was obtained from $\mathrm{I}_{1}$ treatment while the lowest number of tillers per plant (9.96) was obtained from $\mathrm{I}_{2}$ (control) treatment at $125 \mathrm{DAP}$ (Fig. 5). It might be due to soil moisture that created favorable environment to absorb nutrients resulting more number of tillers per plant. This finding agrees with those of Pawar (1990) and Singh et al. (2000). In case of mulch, the maximum number of tillers per plant (13.91) was found in $\mathrm{M}_{2}$ (rice straw mulch) and the lowest 
(9.23) from $\mathrm{M}_{0}$ (control) treatment at 125 DAP (Fig. 6). Possibly mulch conserved t soil moisture in the soil to some extent which helped to produce more number of tillers per plant. Ghosh et al. (2007) and Ghosh (1996) reported that application of straw mulch produced maximum number of tillers per plant.

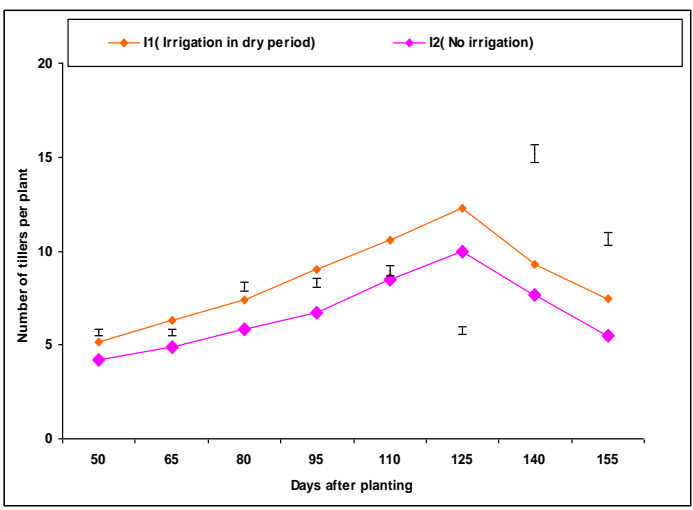

Fig.5. Main effects of irrigation on the number of tillers per plant of ginger. Vertical bars represent LSD at $5 \%$ level of probability

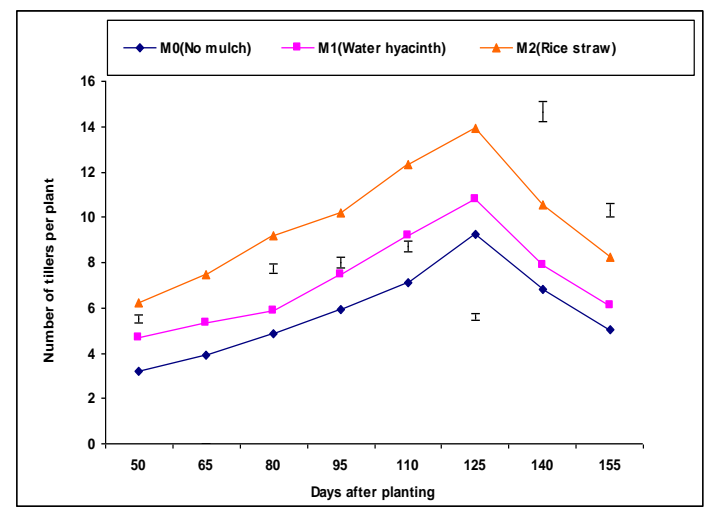

Fig.6. Main effects of mulch on the number of tillers per plant of ginger. Vertical bars represent $\mathrm{LSD}$ at $5 \%$ level of probability

Irrigation treatments had a significant effect on $80 \%$ emergence of seed rhizome (Table 2). The $\mathrm{I}_{1}$ treatment (irrigation in dry period) required the minimum time (27 days) to complete $80 \%$ emergence while it was maximum (45.33 days) in $\mathrm{I}_{2}$ (control) treatment. Similar result was also reported by Pawar, 1990 and Singh et al., 2000. The weight of primary and secondary rhizome varied significantly due to irrigation, mulching and their combination. Different irrigation treatments had significant effect on the weight of primary and secondary rhizome per plant. The $\mathrm{I}_{1}$ (irrigation in dry period) treatment showed the highest yield/plant $(268.07 \mathrm{~g}$ and $60.80 \mathrm{~g}$ ) of primary and secondary rhizome respectively. The lowest yield $(215.81 \mathrm{~g}$ and 51.30 g) primary and secondary rhizome/plant was recorded from $\mathrm{I}_{2}$ (control) treatment respectively (Table 2). This might be due to suitable soil moisture which enhanced rapid growth using the initial reserve food material. Different mulching treatments had significant effect on the weight of primary and secondary rhizome per plant. The maximum weight of primary rhizome $(281.85 \mathrm{~g}) / \mathrm{plant}$ was found from $\mathrm{M}_{2}$ (rice straw mulch) and the lowest $(197.17 \mathrm{~g}) / \mathrm{plant}$ was obtained from $\mathrm{M}_{0}$ (control) treatment (Table 3). Similar trend of result was obtained in case of secondary rhizome per plant where the maximum weight of secondary rhizome per plant was found from $\mathrm{M}_{2}(68.44 \mathrm{~g}) / \mathrm{plant}$ and the lowest from $\mathrm{M}_{0}(45.89 \mathrm{~g}) /$ plant (Table 3). The maximum weight of primary and secondary rhizome per plant in $\mathrm{M}_{2}$ (rice straw mulch) might be due to more soil moisture conserved by this treatment. The weight of primary and secondary rhizome significantly increased due to combined effect of mulching and irrigation treatment. The maximum weight of primary rhizome $(308.94 \mathrm{~g}) /$ plant was recorded from $\mathrm{I}_{1} \mathrm{M}_{2}$ (irrigation in dry period with rice straw mulch) while the lowest $(169.33 \mathrm{~g}) /$ plant was obtained from $\mathrm{I}_{2} \mathrm{M}_{0}$ (control) treatment combination (Table 4). The Maximum weight of secondary rhizome $(75.0 \mathrm{~g}) /$ plant was recorded from $\mathrm{I}_{1} \mathrm{M}_{2}$ (irrigation in dry period + rice straw mulch) while the lowest $(45.00 \mathrm{~g}) /$ plant was obtained from $\mathrm{I}_{2} \mathrm{M}_{0}$ (control) treatment combination (Table 4). Irrigation + rice straw mulch applied plot showed vigorous plants compared to water hyacinth + irrigation and control treatment, which helped in greater deposition accumulation of assimilates 
Islam et al.

to the primary and secondary rhizomes. As a consequence it produced maximum weight of primary and secondary rhizome per plant.

The dry matter of rhizome varied significantly due to irrigation, mulching and their combined effects. The maximum dry matter of rhizome $23.38 \%$ and $23.82 \%$ was found from $\mathrm{I}_{1}$ (irrigation in dry period) and $\mathrm{M}_{2}$ (rice straw mulch), respectively and the minimum $21.50 \%$ and $21.00 \%$ was from $\mathrm{I}_{2}$ (control) and $\mathrm{M}_{0}$ (control), respectively (Table $2 \& 3$ ). In respect of combined effect of irrigation and mulching, it was observed that $\mathrm{I}_{1} \mathrm{M}_{2}$ (irrigation in dry period with rice straw mulch) produced the highest (24.63\%) dry matter of rhizome. It might be due to higher vegetative growth and more accumulation of photosynthates. $\mathrm{I}_{2} \mathrm{M}_{0}$ (control) gave the lowest $(20 \%)$ dry matter of rhizome (Table 4).

Weight of old mother rhizome was significantly influenced by irrigation, mulching and their combination. The maximum (2.55 tha-1 and $\left.2.63 \mathrm{t} \mathrm{ha}^{-1}\right)$ old mother rhizome was recorded from $\mathrm{I}_{1}$ (irrigation in dry period) and $\mathrm{M}_{2}$ (rice straw mulch) treatment, respectively. This finding is similar to Ghosh (1996) that reported the highest weight of old mother rhizomes was obtained from the rice straw mulch treatment. It might be happened due to the fact that the $\mathrm{I}_{1}$ treatment and $\mathrm{M}_{2}$ rice straw mulch conserved more soil moisture which caused more weight of old mother rhizomes. The minimum weight was $\left(1.88 \mathrm{t} \mathrm{ha}^{-1}\right.$ and $\left.1.80 \mathrm{t} \mathrm{ha} \mathrm{C}^{-1}\right)$ from $\mathrm{I}_{2}$ (control) and $\mathrm{M}_{0}$ (control), treatment respectively (Table $2 \& 3$ ). The combined effect of irrigation and mulching significantly influenced the weight of old mother rhizomes. The highest weight $(3.0 \mathrm{t}$ ha $\left.^{-1}\right)$ was obtained from the $\mathrm{I}_{1} \mathrm{M}_{2}$ and the lowest $\left(1.5 \mathrm{tha}{ }^{-1}\right)$ was obtained from the $\mathrm{I}_{2} \mathrm{M}_{0}$ (control) treatment combination (Table 4).

Significant difference in yield $\left(t \mathrm{th}^{-1}\right)$ was observed by the effect of irrigation, mulching and their combination. The maximum yield of $198.74 \mathrm{~g} / \mathrm{plant}, 12.72 \mathrm{~kg} / \mathrm{plot}$ and $21.19 \mathrm{t} \mathrm{ha}^{-1}$ were obtained from $\mathrm{I}_{1}$ (irrigation in dry period) treatment respectively and the lowest $158.15 \mathrm{~g} / \mathrm{plant}$ $10.12 \mathrm{~kg} / \mathrm{plot}$ and $16.87 \mathrm{t} \mathrm{ha}^{-1}$ recorded from $\mathrm{I}_{2}$ (control) treatment (Table 2). The irrigation treatment $\left(\mathrm{I}_{1}\right)$ possibly produced more number of leaves per plant, which helped in higher photosynthates and ultimately resulted accumulation of more food material. This finding agrees with the findings of Pawar (1990) and Singh et al. (2000) who stated that the adequate irrigation increased rhizome yield per hectare.

Beside this, highest yield (211.05 $\mathrm{g} / \mathrm{plant}$ ) was found from $\mathrm{M}_{2}$ treatment (rice straw mulch) and the lowest $(153.61 \mathrm{~g} / \mathrm{plant})$ from $\mathrm{M}_{0}$ (control) treatment (Table 3). The rice straw mulch possibly conserved more soil moisture and suppressed weeds (Table 1), which helped plant growth and deposition of more food materials. Similar result was also reported by Ghosh et al. (2007) who observed the maximum yield per plant from the plants under the paddy straw mulch. The influence of mulching treatment was found significant on the rhizome yield. The height rhizome yield (13.50 kg/plot) was recorded from $\mathrm{M}_{2}$ (rice straw mulch) while the lowest yield $\left(9.83 \mathrm{~kg} / \mathrm{plot}\right.$ ) was found from $\mathrm{M}_{0}$ (control) treatment. Similarly different mulching treatments showed significant effect on the rhizome yield $\mathrm{t}$ ha-1 of ginger. The maximum rhizome yield (22.51 tha-1) was found from $\mathrm{M}_{2}$ treatment and the lowest $\left(16.38 \mathrm{t} \mathrm{ha}^{-1}\right)$ from $\mathrm{M}_{0}$ treatment (Table 3). It might be due to rice straw mulch conserved more soil moisture (Table 1) and suppressed weeds, which helped produce more number of leaves per plant, enhanced plant growth, deposited of more food material and finally gave more yield. Similar results were also found by Mishra and Mishra (1982), Ghosh (1996), and Ghosh et al., 2007). The combined effect irrigation and mulching was found significant on the rhizome yield per plot and yield per hectare. The maximum rhizome yield $(15.04 \mathrm{~kg} / \mathrm{plot})$ was recorded from $\mathrm{I}_{1} \mathrm{M}_{2}$ and the minimum $(8.86 \mathrm{~kg} / \mathrm{plot})$ was found from $\mathrm{I}_{2} \mathrm{M}_{0}$ treatment (Table 4). Similarly the maximum yield of rhizome (25.07 t ha-1) was obtained from $\mathrm{I}_{1} \mathrm{M}_{2}$ while the lowest $\left(14.76 \mathrm{t} \mathrm{ha}^{-1}\right)$ was 
found from $\mathrm{I}_{2} \mathrm{M}_{0}$ treatment combination (Table 4). The treatment $\mathrm{I}_{1} \mathrm{M}_{2}$ was observed better as irrigation and straw mulch conserved more soil moisture and suppressed weed growth. So, crop growth was better with the maximum number of leaves per plant, which helped in photosynthesis and ultimately resulted maximum rhizome yield per hectare. This finding was in agreement with those of Pawar (1990) and Singh et al. (2000). They reported that irrigation with mulching produced the highest yield of rhizomes per hectare.

Table 2. Effect of irrigation on the growth and yield of ginger

\begin{tabular}{|c|c|c|c|c|c|c|c|c|c|}
\hline \multirow[t]{2}{*}{ Treatment } & \multicolumn{4}{|c|}{ Emergence (\%) at DAP } & \multirow{2}{*}{$\begin{array}{l}\text { Wt. of primary } \\
\text { rhizomes/plant } \\
\text { (g) }\end{array}$} & \multirow{2}{*}{$\begin{array}{l}\text { Wt. of } \\
\text { secondary } \\
\text { rhizomes/ } \\
\text { plant (g) }\end{array}$} & \multirow{2}{*}{$\begin{array}{c}\text { Dry } \\
\text { matter } \\
(\%)\end{array}$} & \multirow[b]{2}{*}{$\begin{array}{c}\text { Weight of } \\
\text { old } \\
\text { mother } \\
\text { rhizomes } \\
\left(\mathrm{t} \mathrm{ha}^{-1}\right)\end{array}$} & \multirow{2}{*}{$\begin{array}{l}\text { Rhizome } \\
\text { yield (t } \\
\text { ha-1) }\end{array}$} \\
\hline & 20 & 40 & 60 & 80 & & & & & \\
\hline $\mathrm{I}_{1}$ & 18.00 & 21.33 & 23.33 & 27.00 & 268.07 & 60.80 & 23.38 & 2.55 & 21.19 \\
\hline $\mathrm{I}_{2}$ & 24.33 & 30.00 & 36.67 & 45.33 & 215.81 & 51.30 & 21.50 & 1.88 & 16.87 \\
\hline $\operatorname{LSD}_{(0.05)}$ & 3.31 & 3.74 & 4.59 & 3.81 & 5.08 & 5.95 & 0.57 & 0.39 & 3.87 \\
\hline CV (\%) & 10.53 & 9.83 & 10.31 & 7.10 & 1.42 & 7.17 & 1.73 & 11.89 & 13.75 \\
\hline
\end{tabular}

$\mathrm{I}_{1}$ : irrigation in dry period, $\mathrm{I}_{2}$ : no irrigation, DAP: Days after planting

Table 3. Effect of mulching on the growth and yield of ginger

\begin{tabular}{|c|c|c|c|c|c|c|c|c|c|}
\hline \multirow[b]{2}{*}{ Treatment } & \multicolumn{4}{|c|}{ Emergence (\%) at DAP } & \multirow{2}{*}{$\begin{array}{c}\text { Wt. of primary } \\
\text { rhizomes/plant } \\
\text { (g) }\end{array}$} & \multirow{2}{*}{$\begin{array}{l}\text { Wt. of } \\
\text { secondary } \\
\text { rhizomes/ } \\
\text { plant (g) }\end{array}$} & \multirow{2}{*}{\begin{tabular}{|c|} 
Dry \\
matter \\
$(\%)$
\end{tabular}} & \multirow{2}{*}{$\begin{array}{l}\text { Weight } \\
\text { of old } \\
\text { mother } \\
\text { rhizomes } \\
\text { (t ha-1) }\end{array}$} & \multirow{2}{*}{$\begin{array}{c}\text { Rhizome } \\
\text { yield } \\
\left(\mathrm{t} \mathrm{ha}^{-1}\right)\end{array}$} \\
\hline & 20 & 40 & 60 & 80 & & & & & \\
\hline$\overline{\mathrm{M}_{0}}$ & 25.5 & 31.00 & 35.00 & 39.50 & 197.17 & 45.89 & 21.00 & 1.80 & 16.38 \\
\hline $\mathrm{M}_{1}$ & 20.5 & 25.00 & 29.50 & 36.00 & 246.80 & 53.82 & 22.50 & 2.23 & 18.20 \\
\hline $\mathrm{M}_{2}$ & 17.5 & 21.00 & 25.5 & 33.00 & 281.85 & 68.44 & 23.82 & 2.63 & 22.51 \\
\hline $\operatorname{LSD}_{(0.05)}$ & 2.87 & 3.25 & 3.98 & 3.31 & 4.41 & 5.17 & 0.50 & 0.34 & 3.37 \\
\hline CV (\%) & 10.53 & 9.83 & 10.31 & 7.10 & 1.42 & 7.17 & 1.73 & 11.89 & 13.75 \\
\hline
\end{tabular}

$\mathrm{M}_{0}$ : no mulch, $\mathrm{M}_{1}$ : water hyacinth, $\mathrm{M}_{2}$ : rice straw, DAP: Days after planting

On the other hand mulch had significant effect on $80 \%$ emergence. It was observed that the plants under $\mathrm{M}_{2}$ (rice straw mulch) took the minimum (33.0 days) to complete $80 \%$ emergence while it was maximum (39.5 days) in case of $\mathrm{M}_{0}$ (control) treatment (Table 3). Mulch conserved more soil moisture which enhanced quicker emergence than control treatment. This finding agrees with the finding of Kumar et al. (1973) who observed that mulching enhanced early emergence. Different mulching treatments had significant effect on the weight of primary and secondary rhizome per plant. The maximum weight of primary rhizome $(281.85 \mathrm{~g}) / \mathrm{plant}$ was found from $\mathrm{M}_{2}$ (rice straw mulch) and the lowest $\left(197.17 \mathrm{~g}\right.$ )/plant was obtained from $\mathrm{M}_{0}$ (control) treatment (Table 3). Similar trend of result was obtained in case of secondary rhizome per plant where the maximum weight of secondary rhizome per plant was found from $\mathrm{M}_{2}$ $(68.44 \mathrm{~g}) / \mathrm{plant}$ and the lowest from $\mathrm{M}_{0}(45.89 \mathrm{~g}) /$ plant (Table 3). Beside this, highest yield (211.05 g/plant) was found from $\mathrm{M}_{2}$ treatment (rice straw mulch) and the lowest (153.61 $\mathrm{g} / \mathrm{plant}$ ) from $\mathrm{M}_{0}$ (control) treatment (Table 3). The height rhizome yield $(13.50 \mathrm{~kg} / \mathrm{plot}$ ) was recorded from $\mathrm{M}_{2}$ (rice straw mulch) while the lowest yield $\left(9.83 \mathrm{~kg} / \mathrm{plot}\right.$ ) was found from $\mathrm{M}_{0}$ (control) treatment. Similarly different mulching treatments showed significant effect on the 
Islam et al.

rhizome yield $\mathrm{t}$ ha ${ }^{-1}$ of ginger. The maximum rhizome yield $\left(22.51 \mathrm{t} \mathrm{ha}^{-1}\right)$ was found from $\mathrm{M}_{2}$ treatment and the lowest (16.38 $\mathrm{t} \mathrm{ha}^{-1}$ ) from $\mathrm{M}_{0}$ treatment (Table 3). It might be due to rice straw mulch conserved more soil moisture and suppressed weeds, which helped produce more number of leaves per plant, enhanced plant growth, deposited of more food material and finally gave more yield. Similar results were also found by Mishra and Mishra (1982), Ghosh (1996), and Ghosh et al., 2007).

Table 4. Combined effect of irrigation and mulching on the growth and yield of ginger

\begin{tabular}{|c|c|c|c|c|c|c|c|c|c|c|c|c|c|c|c|c|}
\hline \multirow[t]{2}{*}{ Treatment } & \multicolumn{8}{|c|}{ Plant height $(\mathrm{cm})$ at different days after planting } & \multicolumn{8}{|c|}{ No. of leaves/plant at different days after planting } \\
\hline & 50 & 65 & 80 & 95 & \begin{tabular}{|l|}
110 \\
\end{tabular} & 125 & 140 & 155 & 50 & 65 & 80 & 95 & 110 & 125 & 140 & 155 \\
\hline $\mathrm{I}_{1} \mathrm{M}_{0}$ & 7.9 & 0.40 & 50.00 & 00.00 & 00.93 & 05.13 & 51.80 & 45.93 & 24.77 & 34.80 & 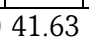 & .53 & 68.53 & 79.00 & 62.80 & 43.17 \\
\hline $\mathrm{I}_{1} \mathrm{M}_{1}$ & 48.62 & 53. & 59 & 63 & & & & & 36. & & & .23 & 2 & 98.05 & 74 & 58.53 \\
\hline $\mathrm{I}_{1} \mathrm{M}_{2}$ & 53.77 & 63. & 67. & 71. & 76 & 79. & 70. & 61.1 & 49.4 & 62.5 & 71 . & 98.6 & 12 & 141. & 11 & 92.00 \\
\hline $\mathrm{I}_{2} \mathrm{M}_{0}$ & 30.66 & 37. & 41 & 44.93 & 46 & 50 & 43 & 30.57 & 20 & 30 & 37 & 49 & 57 & 62.10 & 54.88 & 35.80 \\
\hline $\mathrm{I}_{2} \mathrm{M}_{1}$ & 40.60 & 46.8 & 49. & 51.4 & 56.4 & 61.6 & 52. & 44 & 33. & 41 & 56 & 63.00 & 78.07 & 87.43 & 72.33 & 60.38 \\
\hline $\mathrm{I}_{2} \mathrm{M}_{2}$ & 46.72 & 51.89 & 55.30 & 62.14 & 65.72 & 68.82 & 59.28 & 54.38 & 37.02 & 49.89 & 63.60 & 78.04 & 91.73 & 116.76 & 85.27 & 77.33 \\
\hline CV (\%) & 8.89 & 7.78 & 7.11 & 7.57 & 6.42 & 6.35 & 6.86 & 8.91 & 6.10 & 5.18 & 4.32 & 6.53 & 5.34 & 3.76 & 4.72 & 5.87 \\
\hline
\end{tabular}

Table 4. (Contd.)

\begin{tabular}{|c|c|c|c|c|c|c|c|c|c|c|c|c|c|c|c|c|c|}
\hline \multirow[b]{2}{*}{ Treatment } & \multicolumn{8}{|c|}{ No. of tillers/plant at different days after planting } & \multicolumn{4}{|c|}{ Emergence (\%) } & \multirow{2}{*}{\begin{tabular}{|c} 
Wt. of \\
primary \\
rhizomes \\
plant (g)
\end{tabular}} & \multirow{2}{*}{\begin{tabular}{|c|} 
Wt. of \\
secondary \\
rhizomes/ \\
plant (g)
\end{tabular}} & \multirow{2}{*}{\begin{tabular}{|c|} 
Dry \\
matter \\
$(\%)$
\end{tabular}} & \multirow[b]{2}{*}{$\begin{array}{l}\text { Weight } \\
\text { of old } \\
\text { mother } \\
\text { rhizomes } \\
\left(\mathrm{t}_{\text {ha }}{ }^{-1}\right)\end{array}$} & \multirow{2}{*}{$\begin{array}{c}\text { Rhizome } \\
\text { yield (t ha } \\
1 \text { ) }\end{array}$} \\
\hline & 50 & 65 & 80 & 95 & 110 & 125 & 140 & 155 & 20 & 40 & 60 & 80 & & & & & \\
\hline $\mathrm{I}_{1} \mathrm{M}_{\mathrm{C}}$ & 3.53 & 4.14 & 5.02 & 6.47 & 7.73 & 10.13 & 7.43 & 5.73 & 21.0 & 24.0 & 26.0 & 30.0 & 225.00 & 46.78 & 22.00 & 2.10 & 18.00 \\
\hline $\mathrm{I}_{1} \mathrm{M}_{1}$ & 4.91 & 6.18 & 6.37 & 8.57 & 9.86 & 11.84 & 8.28 & 7.01 & 18.0 & 22.0 & 24.0 & 27.0 & 270.26 & & 23.5 & & 20 \\
\hline $\mathrm{I}_{1} \mathrm{M}_{2}$ & 7.06 & 8.60 & 10.88 & 12.10 & 14.17 & 15.97 & 11.98 & 9.59 & 15.0 & 18.0 & 20.0 & 24.0 & 308.94 & & 24.63 & & 25.07 \\
\hline $\mathrm{I}_{2} \mathrm{M}_{0}$ & 2.83 & 3.67 & 4.68 & 5.37 & 6.47 & 8.33 & 6.23 & 4.30 & 30.0 & 38.0 & 44.0 & 49.0 & 169 & 45 & 20 & & 14.76 \\
\hline $\mathrm{I}_{2} \mathrm{M}_{1}$ & 4.43 & 4.50 & 5.33 & 6.40 & 8.47 & 9.69 & 7.53 & 5.19 & 23.0 & 28.0 & 35.0 & 45.0 & 223 & 47 & 21.50 & 1. & 15.89 \\
\hline $\mathrm{I}_{2} \mathrm{M}_{2}$ & 5.37 & 6.37 & 7.51 & 8.30 & 10.50 & 11.85 & 9.17 & 6.89 & 20.0 & 24.0 & 31.0 & 42.0 & 254.75 & 61.87 & 23.0 & 2.25 & 19.95 \\
\hline D & 0.87 & 0.87 & 1.23 & 1.27 & 1. & .89 & 2.3 & 1.64 & 4.06 & 4.59 & 5.6 & 4.6 & 6. & r. & 0.7 & & $T$. \\
\hline CV $(8$ & 10.21 & 8.61 & 10.23 & 8.88 & 7.97 & 4.31 & 15.22 & 13.98 & 10.53 & 9.83 & 10.31 & 7.10 & 1.42 & 7.17 & 1.73 & 11.89 & 13.75 \\
\hline
\end{tabular}

$I_{1}$ : irrigation in dry period, $I_{2}$ : no irrigation, $M_{0}$ : no mulch, $M_{1}$ : water hyacinth mulch, $M_{2}$ : rice straw mulch, DAP: Days after planting

In case of combined effect the, maximum (49.0 days) were recorded in $\mathrm{I}_{2} \mathrm{M}_{0}$ (control) treatment while the minimum (24.0 days) were required in $\mathrm{I}_{1} \mathrm{M}_{2}$ (irrigation in dry period with rice straw mulch) treatment combination (Table 4). It might be due to the fact that irrigation and mulching conserved soil moisture, reduced soil temperature, minimized the evaporation loss, and enhanced root growth. This finding agrees with those of Chowdhury and Prihar (1974), Pawar (1990) and Ghosh et al. (2007). The combined effect of irrigation and mulching on plant height was significant from 50 to 155 DAP. The tallest plant $(79.76 \mathrm{~cm})$ was recorded from $\mathrm{I}_{1} \mathrm{M}_{2}$ (irrigation in dry period with rice straw mulch) and the shortest plant $(50.87 \mathrm{~cm})$ from $\mathrm{I}_{2} \mathrm{M}_{0}$ (control) at 125 DAP (Table 4). It might be possible due to irrigation with rice straw mulching reduced soil temperature, conserved soil moisture, minimize the evaporation loss and enhances root growth and water use efficiency. So, plant was vigorous and rapid growth. This finding agreed with the finding of Zaman et al. (2002) and Mishra and Mishra (1982). Almost similar trend regarding number of leaves per plant was obtained by Ghosh et al. (2007). In case of combined effect the highest number of leaves (141.80) was counted in the $\mathrm{I}_{1} \mathrm{M}_{2}$ (irrigation in 
dry period with rice straw mulch) while the lowest (62.10) was obtained from $\mathrm{I}_{2} \mathrm{M}_{0}$ (control) treatment combinations at 125 DAP (Table 4). It might be due to that irrigation supplied water and mulch conserved moisture in the soil to some extend which was used by the plants to promote more number of leaves per plants Ghosh (1996) obtained higher number of leaves per plant from rice straw mulch. The maximum weight of primary and secondary rhizome per plant in $\mathrm{M}_{2}$ (rice straw mulch) might be due to more soil moisture conserved by this treatment. The weight of primary and secondary rhizome significantly increased due to combined effect of mulching and irrigation treatment. The maximum weight of primary rhizome $(308.94 \mathrm{~g}) / \mathrm{plant}$ was recorded from $\mathrm{I}_{1} \mathrm{M}_{2}$ (irrigation in dry period with rice straw mulch) while the lowest $(169.33 \mathrm{~g}) /$ plant was obtained from $\mathrm{I}_{2} \mathrm{M}_{0}$ (control) treatment combination (Table 4). The Maximum weight of secondary rhizome $(75.0 \mathrm{~g}) /$ plant was recorded from $\mathrm{I}_{1} \mathrm{M}_{2}$ (irrigation in dry period + rice straw mulch) while the lowest $(45.00 \mathrm{~g}) /$ plant was obtained from $\mathrm{I}_{2} \mathrm{M}_{0}$ (control) treatment combination (Table 4). Irrigation + rice straw mulch applied plot showed vigorous plants compared to water hyacinth + irrigation and control treatment, which helped in greater deposition accumulation of assimilates to the primary and secondary rhizomes. As a consequence it produced maximum weight of primary and secondary rhizome per plant. In respect of combined effect of irrigation and mulching, it was observed that $\mathrm{I}_{1} \mathrm{M}_{2}$ (irrigation in dry period with rice straw mulch) produced the highest (24.63\%) dry matter of rhizome. It might be due to higher vegetative growth and more accumulation of photosynthates. $\mathrm{I}_{2} \mathrm{M}_{0}$ (control) gave the lowest (20\%) dry matter of rhizome (Table 4). The combined effect of irrigation and mulching significantly influenced the weight of old mother rhizomes. The highest weight $\left(3.0 \mathrm{t} \mathrm{ha}^{-1}\right)$ was obtained from the $\mathrm{I}_{1} \mathrm{M}_{2}$ and the lowest $\left(1.5 \mathrm{t} \mathrm{ha}^{-1}\right)$ was obtained from the $\mathrm{I}_{2} \mathrm{M}_{0}$ (control) treatment combination (Table 4). The combined effect irrigation and mulching was found significant on the rhizome yield per hectare. The maximum rhizome yield $(15.04 \mathrm{~kg} / \mathrm{plot})$ was recorded from $\mathrm{I}_{1} \mathrm{M}_{2}$ and the minimum $(8.86 \mathrm{~kg} / \mathrm{plot})$ was found from $\mathrm{I}_{2} \mathrm{M}_{0}$ treatment (Table 4). Similarly the maximum yield of rhizome $\left(25.07 \mathrm{t} \mathrm{ha}^{-1}\right)$ was obtained from $\mathrm{I}_{1} \mathrm{M}_{2}$ while the lowest (14.76 tha-1) was found from $\mathrm{I}_{2} \mathrm{M}_{0}$ treatment combination (Table 4). The treatment $\mathrm{I}_{1} \mathrm{M}_{2}$ was observed better as irrigation and straw mulch conserved more soil moisture and suppressed weed growth. So, crop growth was better with the maximum number of leaves per plant, which helped in photosynthesis and ultimately resulted in maximum rhizome yield per hectare. This finding was in agreement with those of Pawar (1990) and Singh et al. (2000). They reported that irrigation with mulching produced the highest yield of rhizomes per hectare. The combined effect of irrigation and mulching was significant to influence the number of tillers per plant. The highest number of tillers per plant (15.97) was counted from $\mathrm{I}_{1} \mathrm{M}_{2}$ and the lowest (8.33) from $\mathrm{I}_{2} \mathrm{M}_{0}$ (control) treatment combination at 125 DAP (Table 4). This might be due to $\mathrm{I}_{1} \mathrm{M}_{2}$ irrigation and mulch reduced soil temperature fluctuation, minimized evaporation loss, conserved soil moisture, enhanced root growth and produced more number of tillers per plant. Almost similar trend in number of tillers per plant was obtained by Ghosh (1996). Ghosh (2007) reported that plants with rice straw mulch produced maximum number of tillers per plant followed by water hyacinth.

\section{Conclusion}

The study concluded that the rhizome yield of ginger was significantly affected by the irrigation, mulching and their combined effects. The growth and yield attributes of ginger rhizome were increased when irrigation as applied irrigation in dry period ( 7 days before planting and 60 days after planting). Mulching also influenced the growth and yield of ginger rhizome. The rice straw mulch gave the highest yield of ginger rhizome. However, irrigation in dry period with rice 
Islam et al.

straw mulch resulted in the highest rhizome yield per unit area. Further investigation is needed in suggested for different agro-ecological region of Bangladesh in order to confirm the present findings.

\section{References}

Awal, M. A., M. M. Hossain and M. M. Rashid. 1978. The effect of methode of seed bed preparation, mulching and intertillage on the growth and yield of Mukhi kachu (Colocasia esculenta var. globulifera). Bangladesh Hort. 6(1-2): 9-13.

Chandra, R., G. Sheo, R. Chandra and S. Goving. 2001. Effect of mulching on yield of ginger. J. Spices Aromatic crops 10(1): 13-16.

Chowdhury, M. R and S. S. Prihar. 1974. Root development and growth response of corn following mulching. Cultivation and inter row compaction. Agron. J. 66: 350-355.

Ghosh, D. K., J. K. Hoer, A. Bandopadhyay, N. Chattopadhyay and S. S. Roy. 2007. Effect of spacing and rhizome size on yield of turmeric grown as intercrope in coconut plantation. Seminar heald on Bidhan Chandra Krishi, Viswavidyalaya Mohanpur 741252, Nadia, West Bengal, India.

Ghosh. K. S. 1996. Effect of spacing and mulching on the growth and yield of ginger (Zingiber officinale Rosc.). M. S. thesis. Department of Horticulture, BAU, Mymensingh, pp. 38.

Jha, R.C., K.R. Maurya and R.D. Pandey. 1986. Influence of mulching on the yield of ginger in Bihar. Indian Cocoa Arecanut Spices J. 9(4):87-90.

Kumar, C. R. M., R. C. Mandal and K. D. Singh. 1973. Effect of mulching and plant density on growth, yield and quality of Amorphophallus. Indian J. Agron., 18(1): 62-66.

Mannan, M.A. and M. M. Rashid. 1983. Effect of spacing and mulching on the yield and profitability of Pancha Mukhi Kachu. Bangladesh J. Agril. Res. 8(2): 70-73.

Mishra, S. and S. S. Mishra. 1982. Effect of mulching and weedicides on growth and fresh rhizome yield of ginger. Annual Conference of Indian Society of Weed Science, 1982 (Undated) 33.

Mohanthy, D. C., Y. N. Serma and B. S. Panda. 1991. Effect of mulch materials and intercrops on the yield of turmeric under rain fed conditions. Indian Cocoa Arecanut Spices J. 15(1): 811.

Nick, J., J. E. Moody and J. H. Lillard. 1969. Effect of number of tillage and mulch on Soil water and plant growth. Agron. J. 61(15): 719-721.

Onwueme, I. C. 1978. The Tropical Tuber Crops. John Wiley and Sons, Chichester, pp. 199-227.

Pawar, H. K. 1990. Use of plastic as a mulch in scheduling of irrigation to ginger in semi- arid climate. Proceedings of the $11^{\text {th }}$ international congress on the use of plastics in agriculture, New Delhi, India, 26 ${ }^{\text {th }}$ February- $2^{\text {nd }}$ March. E.99- E.109.

Pruthi, J. S. 1998. Spices and Condiments. Nation Book Trust, New Delhi, pp. 147-152.

Singh, J. P., Prasad, U. K. and H. Singh. 2000. Effect of irrigation and drainage requirement on water-use efficiency and yield pure (crops turmeric) and maize based inter crops. Indian J. Agril. Sci. 70(2): 65-68.

Zaman, M. M., A. S. M. H. Masum, N. U. Ahmed, M. A. Salam and M. H. Rahman. 2002. Effect of tillage and mulch on the growth and yield of ginger in the hilly area. Online J. Biol. Sci. 2(2): 121-123. 